\title{
ORIGINALS
}

\section{Beta-Adrenergic Stimulation and Insulin Release in Dogs Following HB 419}

\author{
O.V. Sirek, M. Vigas, A. Niki, H. Niki and A. Sirek \\ Department of Physiology, and Division of Laboratory Teaching, University of Toronto, Toronto, Canada
}

Received: February 10, 1969

Summary. A new hypogylcaemic sulphonylurea HB 419 (Glybenzcyclamide) was injected intravenously into normal dogs $(0.25 \mathrm{mg} / \mathrm{kg})$. The drug produced within $30 \mathrm{~min}$ a fall in the concentration of plasma glucose and a rise in the concentration of immunoreactive insulin (IRI). When the alpha-adrenergic blocking agent phentolamine (5 $\mathrm{mg}$ per dog) was injected prior to the administration of $\mathrm{HB} 419$, the rise in the concentration of plasma IRI was markedly potentiated. Insulin secretion was not appreciably stimulated by $\mathrm{HB} 419$ when animals were treated with the beta-adrenergic blocking agent Kö 592, 1-(3-methylphenoxy)-3-isopropylaminopropanol2-hydrochloride $(0.1 \mathrm{mg} / \mathrm{kg})$. The results of these experiments suggest that the mechanism of action of HB 419 on the pancreatic islets involves beta-adrenergic stimulation.

Stimulation bêta-adrénergique et libération d'insuline après administration de $H B 419$ chez le chien

Résumé. Un nouveau sulfonylurée hypoglycémiant, le HB 419 (glybenzcyclamide) a été injecté par voie intraveineuse à des chiens normaux $(0.25 \mathrm{mg} / \mathrm{kg})$. Dans les $30 \mathrm{~min}$, la drogue provoquait une chute de la concentration de glucose plasmatique et une augmentation de la concentration d'insuline immunoréactive (IRI). Lorsque l'on injectait de la phentolamine (5 mg par ehien), agent bloquant alpha-adrénergique, avant l'administration de H.B 419 , l'élévation de la concentration d'IRI plasmatique était potentialisée de façon prononcée. La sécrétion d'insuline n'était pas stimulée de façon appréciable par le HB 419 quand les animaux étaient traités avec un agent bloquant bêta-adrénergique, le Kö 592, chlorhydrate de 1-(3-méthylphenoxy)-3-isopropylaminopropanol-2 $(0.1 \mathrm{mg} / \mathrm{kg})$. Les résultats de ces expériences suggèrent que le mécanisme d'action du HB 419 sur les îlots pancréatiques implique la stimulation bêta-adrénergique.

Beta-adrenerge Stimulation und Insulinausschüttung bei Hunden unter $H B 419$

Zusammenfassung. Normale Hunde erhielten 0.25 $\mathrm{mg} / \mathrm{kg}$ des neuen blutzuckersenkenden Sulfonylharnstoffs HB 419 (Glybenzeyclamid) intravenös. Das Mittel rief innerhalb einer halben Stunde einen Abfall des Blutzuckers und einen Anstieg der Serumspiegel des immunoreaktiven Insulins (IRI) hervor. Die Erhöhung der Seruminsulinspiegel ließ sich wesentlich verstärken, wenn vor der HB 419-Gabe der alpha-Rezeptorenblocker Phentolan (5 mg/Hund) verabreicht wurde. Die Zufuhr des $\beta$-Rezeptorenblockers Kö 592, 1-(3-methylphenoxy)-3-isopropylaminopropanol-2-hydrochlorid $(0.1 \mathrm{mg} / \mathrm{kg})$ hob den HB 419-Effekt auf die Insulinsekretion weitgehend auf. Die Untersuchungsergebnisse deuten darauf hin, daß die Wirkung von HB 419 auf die Pankreasinseln über eine $\beta$ adrenerge Stimulation erfolgt.

Key-words: Plasma insulin, alpha-adrenergic blockade, beta-adrenergic blockade.
In humans direct stimulation of beta-adrenergic receptors by isoproterenol was shown to lead to an increase in the concentration of immunoreactive insulin [5], whereas stimulation of alpha-adrenergic receptors by epinephrine caused inhibition of insulin release [6, 7]. Glucagon exerted its insulin releasing effect in spite of beta-adrenergic blockade [5], and alphaadrenergic stimulation by epinephrine caused partial inhibition of the insulinogenic effect of tolbutamide [7]. Although the latter could not be interpreted in terms of direct participation of adrenergic receptors in the mechanism of action of tolbutamide, we have, nevertheless, considered the possible involvement of alphaand/or beta-adrenergic receptors in the mechanism of action of the newly introduced oral hypoglycaemic sulphonylurea Glybenzcyclamide, better known as HB 419 [10].

\section{Methods}

Four normal mongrel dogs, each weighing about $10 \mathrm{~kg}$, were fasted overnight and used for experimentation without anaesthesia. The sodium salt of HB 419, a gift of Hoechst Pharmaceuticals of Canada, was in- jected intravenously either alone $(0.25 \mathrm{mg} / \mathrm{kg}$, representing 10 times the minimum effective dose), or following pre-treatment with one of the adrenergic blocking agents. Phentolamine (Rogitine, $5 \mathrm{mg}$ per dog) was used to block the alpha-adrenergic receptors; the drug was a gift of the Ciba Co. To block the beta-adrenergic receptors, we used Kö 592, 1-(3-methylphenoxy)-3isopropylaminopropanol-2-hydrochloride $(0.1 \mathrm{mg} / \mathrm{kg})$, which was a gift of the firm C.H. Boehringer \& Sohn. In control experiments, phentolamine and Kö 592 were each injected alone. The arrangement of the experiments was such that each dog was its own control. Samples of blood were withdrawn from a vein of the foreleg into heparinized syringes at 15 or $30 \mathrm{~min}$ intervals. Plasma sugar was determined by the ferricyanide method of HoffmaN [2], using a Technicon AutoAnalyzer. Plasma immunoreactive insulin (IRI) was assayed according to YALOW and BtRsoN [12].

\section{Results}

Although each of the adrenergic blocking agents was injected in relatively large amounts, none of them 
per se affected blood sugar levels or IRI concentrations of normal dogs (Figs. 1, 2, 3).

HB 419 alone decreased the blood sugar level by
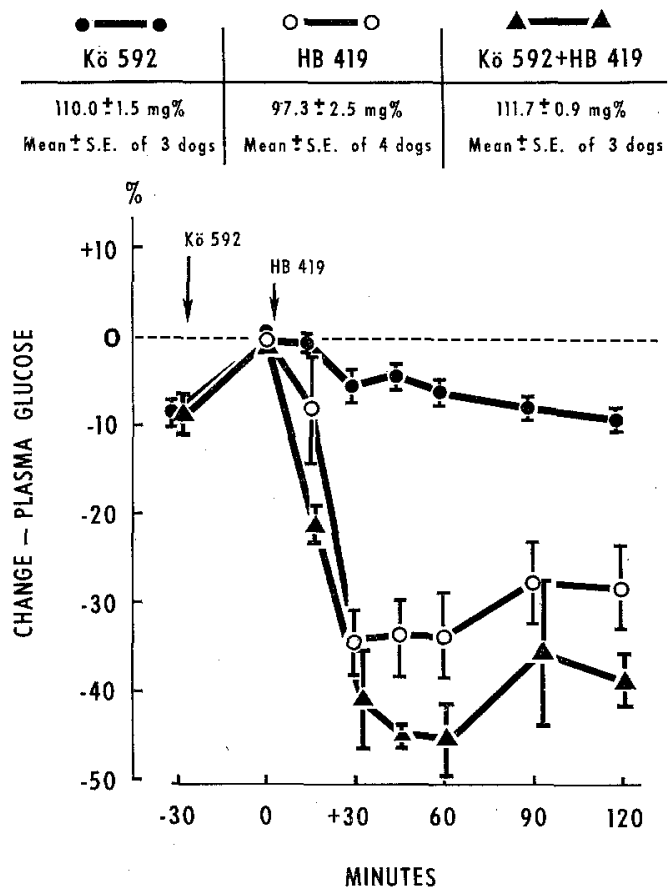

Fig. 1. Plasma glucose response to a single i.v. injection of a) the hypoglycaemic sulphonylurea HB $419(0.25 \mathrm{mg} / \mathrm{kg})$; b) the beta-adrenergic blocking compound Kö 592 $(0.1 \mathrm{mg} / \mathrm{kg})$; and c) the combination of the two agents

\begin{tabular}{|c|c|c|}
\hline Pheniolamine & 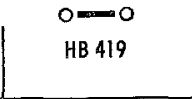 & $\begin{array}{c}\Delta=\mathbf{\Delta} \\
\text { Phentolamine + } \\
\text { HB } 419\end{array}$ \\
\hline $\begin{array}{c}92.7 \pm 2.2 \mathrm{mg} \% \\
\pm \text { e.e. of } 3 \mathrm{dog}\end{array}$ & $\begin{array}{c}97.3 \pm 2.5 \mathrm{mg} \% \\
\text { mean } \div \text { S.E: of } 4 \text { dogs }\end{array}$ & $\begin{array}{c}96.7 \pm 2.9 \mathrm{mg} \% \\
\text { Meon } \pm \text { S.E. of } 3 \mathrm{dogs}\end{array}$ \\
\hline
\end{tabular}

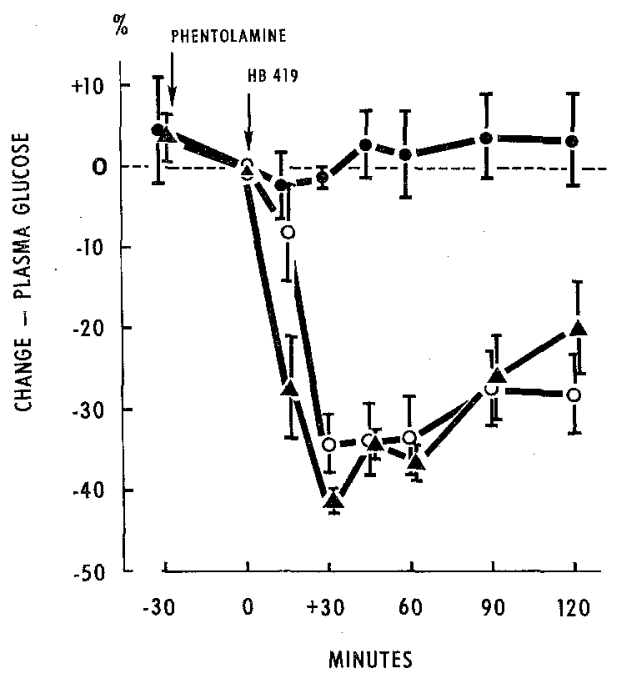

Fig. 2. Plasma glueose response to a single i.v. injection of a) the hypoglycaemic sulphonylurea HB $419(0.25 \mathrm{mg} / \mathrm{kg})$;

b) the alpha-adrenergic blocking compound phentolamine

$(5 \mathrm{mg}$ per dog); and c) the combination of the two agents some $35 \%$ within thirty minutes. Pre-treatment with either phentolamine or Kö 592 did not influence the hypoglycaemic effect of HB 419 (Figs. 1 and 2).

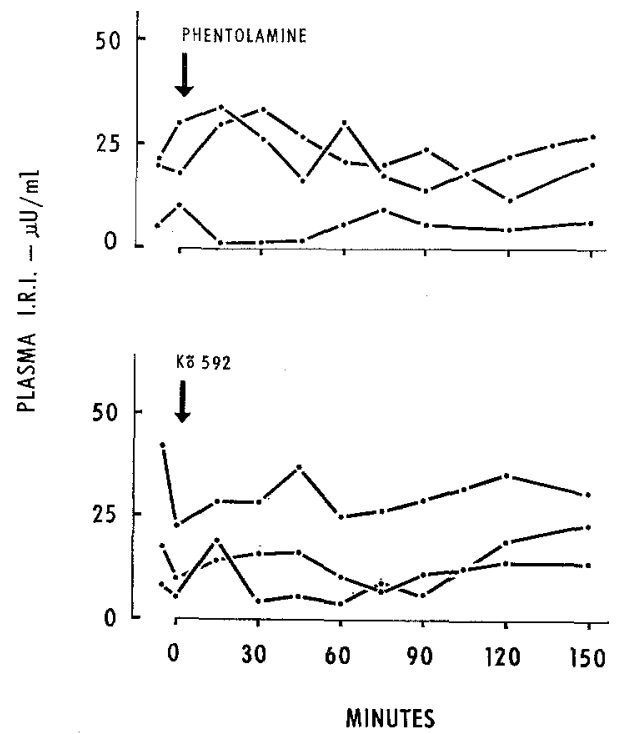

Fig. 3. Plasma insulin levels following a single i.v. injection of the alpha-receptor blocking agent phentolamine (5 $\mathrm{mg}$ per dog) and the beta-receptor blocking agent Kö $592(0.1 \mathrm{mg} / \mathrm{kg})$

As far as insulin is concerned, administration of HB 419 alone caused within thirty minutes a two-to sixfold increase in the concentration of plasma IRI (Figs. 4 and 5). When phentolamine was injected prior to the administration of HB 419, the increase in the concentration of plasma IRI became very marked in each dog, reaching within the first thirty minutes values that were approximately twice as high as the maximal concentrations obtained with $\mathrm{HB} 419$ alone (Fig. 4). No such potentiated insulin release was seen

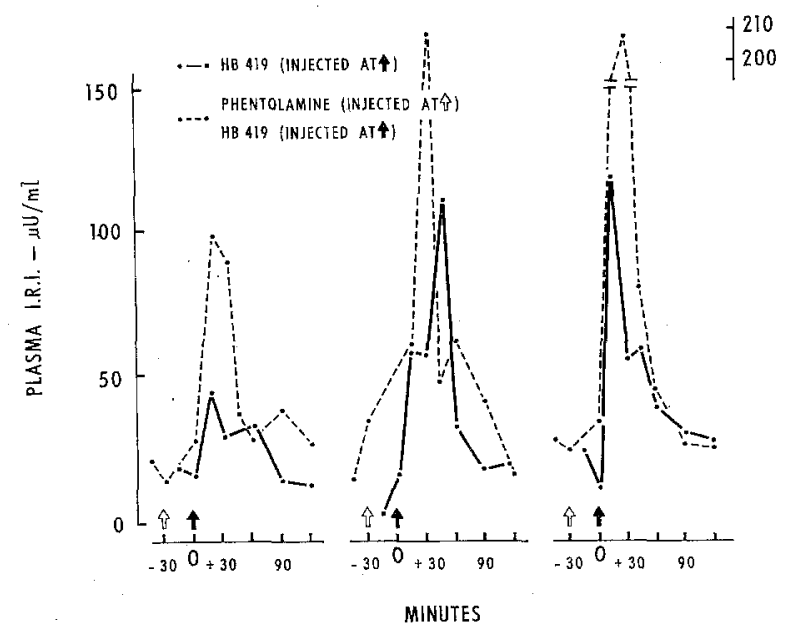

Fig. 4. Plasma insulin concentrations rose in (three) normal dogs following a single i.v. injection of $\mathrm{HB} 419$ $(0.25 \mathrm{mg} / \mathrm{kg})$. Note the augmented response when the animals were pretreated with phentolamine $(5 \mathrm{mg}$ per dog) 
when the animals were pre-treated with Kö 592 instead of phentolamine; HB 419 stimulated no peak insulin secretion in 2 out of 3 dogs (Fig. 5).

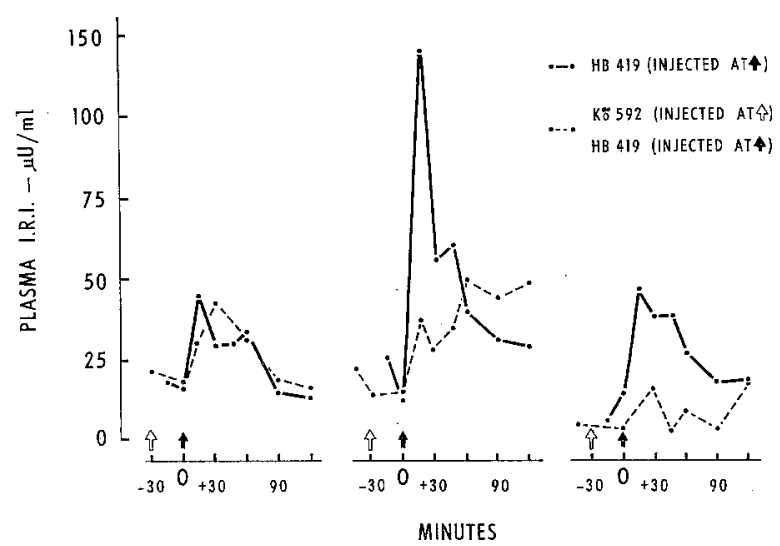

Fig. 5. Plasma insulin levels were not augmented in response to HB $419(0.25 \mathrm{mg} / \mathrm{kg})$ when the animals were pretreated with $\mathrm{Kö} 592(0.1 \mathrm{mg} / \mathrm{kg})$; the sulphonylurea failed to raise insulin concentrations in 2 out of 3 dogs

\section{Discussion}

The results of our experiments indicate that HB 419 releases insulin from the pancreatic islet cells by a mechanism which involves beta-adrenergic receptors.

SUTHERLAND and collaborators [8] have forwarded the hypothesis that the beta-adrenergic receptor is likely to be identical with a part of the adenyl cyclase, the enzyme which catalyzes the conversion of ATP (adenosine triphosphate) to cyclic AMP (adenosine $3^{\prime}, 5^{\prime}$-monophosphate). A possible role for the adenyl cyclase system in insulin secretion was investigated by Malaisse, Malatsse-Lagae and Mayhew [3]; exogenous cyclic AMP was shown to have an insulin releasing effect by Sussman and Vaughian [11]. Recently, it has also been suggested that tolbutamide may release insulin from the islets through cyclic AMP: The effect of tolbutamide was potentiated by caffeine [4], which is known to inhibit phosphodiesterase, the enzyme which inactivates cyclic AMP [9].

Thus even though we have not studied the levels of cyclic AMP in the pancreatic beta cells of our dogs, the evidence derived from our experimental results and from the recent literature favours the hypothesis that HB 419 stimulated the release of insulin, at least in part, by activating the synthesis of cyclic AMP through the adenyl cyclase system.

Although a reduction in plasma glucose concentration at high plasma insulin levels is to be expected, the reduction which we have noticed in the presence of relatively low insulin levels after injecting HB 419 in combination with Kö 592 requires comment. Since hepatic glycogenolysis is mediated by eyclic AMP $[8,9]$, a beta-adrenergic blockade of the adenyl cyclase may result in the dog in an inhibition of the glycolytic mechanism [8], and hypoglycaemia will follow. An observation similar to ours was made by ByERs and FrIEDMan [1]. Administration of the beta-adrenergic blocker propranolol in combination with small amounts of insulin to rats resulted in hypoglycaemic convulsions. It was suggested that the beta-blocker inhibited the glycolytic reactions normally induced by epinephrine when the blood sugar level was low.

Augmentation of the IRI response, as observed after the combined administration of phentolamine and $\mathrm{HB} 419$, also requires comment. Stimulation of alpha-receptors inhibits the secretion of insulin $[6,7]$, and presumably this is achieved by a decrease in the level of cyclic AVIP $[8,9]$. Pharmacological blockade of these receptors enhances the effectiveness of the beta-receptors [6], which may explain in part the augmented IRI response as demonstrated in Fig. 4. Also, in the case of HB 419 it is likely that the hypoglycaemia remained "unopposed", in that epinephrine was unable to act on the blocked alpha-receptors, and consequently the IRI concentrations were permitted to rise to levels almost twice as high as those observed when the alpha-receptors were in operation. Whether or not sufficient amounts of endogenous epinephrine were released, which could account for a direct stimulation of the islet cells when under alpha-adrenergic blockade $[5,6,9]$, remains to be studied. The possibility cannot be excluded, since comparable reductions in plasma glucose concentrations (Fig. 2) were observed at insulin concentrations as far apart as $50 \mu \mathrm{U} / \mathrm{ml}$ and $200 \mu \mathrm{U} / \mathrm{ml}$ (Fig. 4). This would indeed suggest that more epinephrine was released for compensatory glycogenolysis in response to the combined administration of phentolamine and $\mathrm{HB} 419$, than following HB 419 alone.

\section{References}

1. Byers, S. O., and M. Friedmar : Insulin hypoglycemia enhanced by beta adrenergic blockade. Proc. Soc. exp. Biol. 122, 114-115 (1966).

2. Hoffman, W.S.: A rapid photoelectric method for the determination of glucose in blood and urine. $\mathrm{J}$. biol. Chem. 120, 51-55 (1937).

3. Malaisse, W.J., F. Malaisse-Lagae, and D. MayHEW : A possible role for the adenylcyclase system in insulin secretion. J. clin. Invest. 46, 1724-1734 (1967).

4. Lambert, A.E., B. Jeanrenadd, and A.E. Renold: Enhancement by caffeine of ghucagon-induced and tolbutamide-induced insulin release from isolated foetal pancreatic tissue. Lancet 1967 I, 819-820.

5. Porte, D. Jr.: Beta adrenergic stimulation of insulin release in man. Diabotes $16,150-155(1967)$.

6. - A receptor mechanism for the inhibition of insulin release by epinephrine in man. J. clin. Invest. 46, $86-94$ (1967).

7. - A.L. Graber, T. KuzuYa, and R.H. Wiltiams: The effect of epinephrine on immunoreactive insulin levels in man. J. clin. Invest. 45, 228-236 (1966).

8. Robison, G.A., R.W. Butcher, and E.W. SutherLAND : Adenyl cyclase as an adrenergic receptor. Ann. N.Y. Acad. Sci. 139, 703-723 (1967).

9. - - Cyclic AMP. Ann. Rev. Biochem. 37, 149$174(1968)$. 
10. Schörfing, K.: Stand der Therapie mit Sulfonylharnstoffen und Biguaniden. Therapiewoche 1, 11-20 (1968).

11. Sussman, K.E., and G.D. VAughan: Insulin release after ACTH, glueagon and adenosine-3'-5' $5^{\prime}$-phosphate (cychic AMP) in the perfused isolated rat pancreas. Diabetes 16, $449-454$ (1967).
12. YALOW, R.S., and S.A. Berson: Immunoassay of plasma insulin. Meth. biochem. Anal. 12, 69-96 (1964).

\section{Prof. O.V. SIREK}

Department of Physiology

University of Toronto

Toronto, Canada 